\title{
POU-domain proteins Pit-1 and Oct-1 interact to form a heteromeric complex and can cooperate to induce expression of the prolactin promoter
}

\author{
Jeffrey W. Voss, ${ }^{2}$ Laura Wilson, ${ }^{1}$ and Michael G. Rosenfeld ${ }^{1,2}$ \\ ${ }^{1}$ Howard Hughes Medical Institute, ${ }^{2}$ Eukaryotic Regulatory Biology Program and Center for Molecular Genetics, \\ School of Medicine, University of California, San Diego, La Jolla, California 92093-0648 USA
}

\begin{abstract}
Two members of the POU-domain family of transcriptional activators, Pit-1 and Oct-1, are coexpressed in cells of the anterior pituitary gland. We demonstrate that the pituitary-specific developmental regulator Pit-1 can bind as a heterodimer with the widely expressed 100-kD Oct-1 protein to critical tissue-specific cis-active elements in the rat prolactin gene. Pit-1 and Oct-1 can also associate, in the absence of DNA, via their POU domains. Coexpression of Pit-1 and Oct-1 in a heterologous cell type results in reproducible 2 - to 2.5 -fold synergistic transcriptional effects on genes under control of the native prolactin promoter or of a single Pit-1 response element. These results suggest that a combinatorial pattern of heterodimeric and homodimeric interactions between different members of the POU-domain gene family can result when members of this large family are coexpressed in cells of developing and established organ systems, potentially regulating differential developmental gene activation.
\end{abstract}

[Key Words: Pou-domain family; transcriptional activators; Pit-1; Oct-1; prolactin promoter]

Received October 25, 1990; revised version accepted April 11, 1991

Definition of the interactions between proteins that recognize cis-active sites conferring tissue-specific gene expression is central to understanding the development of organ systems. Tissue-specific targeting and regulation of the rat prolactin gene to cells of the anterior pituitary gland are conferred by the synergistic action of two upstream regulatory elements-the distal enhancer and proximal promoter (Nelson et al. 1988; Crenshaw et al. 1989). Within these elements is a complex arrangement of binding sites for trans-acting factors that confers tissue-specific expression and potentiates transcription. A number of these sites are recognized by the pituitaryspecific POU-domain transcription factor Pit-1. The ability of Pit-1 to control prolactin gene transcription has been demonstrated repeatedly (Schuster et al. 1987; Cao et al. 1988; Ingraham et al. 1988, 1990; Nelson et al. 1988; Mangalam et al. 1989; Elsholtz et al. 1990; Fox et al. 1990; Larkin et al. 1990). The demonstration that Pit1 gene dysfunction accounts for genetically dwarfed mice that fail to express the prolactin gene links Pit-1 function to transcriptional activation of the prolactin gene in the anterior pituitary (Li et al. 1990).

The POU family of transcriptional regulators (Bodner et al. 1988; Clerc et al. 1988; Finney et al. 1988; Ingraham et al. 1988; Ko et al. 1988; Müller et al. 1988; Scheidereit et al. 1988; Sturm et al. 1988; Burgin et al. 1989; He et al. 1989; Johnson and Hirsh 1990; Okamoto et al. 1990; Rosner et al. 1990; Schöler et al. 1990) shares a novel motif, the POU domain, which can be divided into two regions designated as the POU-specific domain and POU homeo domains (Herr et al. 1988). Several POU-domain proteins are coexpressed in cells of the neural and endocrine systems during normal development (He et al. 1989). Although Pit-1 is expressed exclusively in three cell types of the anterior pituitary, the POU-domain protein Oct-1 appears to be expressed in a wide variety of cell types. Analysis of Pit-1 ontogeny reveals a close correlation between the initial appearance of Pit-1 on embryonic day 15.5 of development (Simmons et al. 1990| and the activation of the prolactin and growth hormone genes on embryonic days 16 and 17 (Crenshaw et al. 1989; Simmons et al. 1990). Oct-1, however, is expressed much earlier, on embryonic day 8 in the egg cylinder (He et al. 1989). The highest-affinity binding site in the rat prolactin gene promoter $(\operatorname{Prl}-1 \mathrm{P})$ is that most proximal to the TATA box. Oct-1 also binds to this element (Elsholtz et al. 1990) as well as to similar Pit-1-binding sites that are present in other pituitaryspecific genes such as the Pit-1 gene itself /Chen et al. 1990). The coexpression of the related Pit-1 and Oct-1 proteins in the developing pituitary gland and their common affinity for regulatory elements present in pituitary specific genes suggested that these proteins might interact. Heterodimer formation between related proteins has 
been predicted to be critical in dictating developmentally regulated events such as myogenesis (Murre et al. 1989a,b; Davis et al. 1990).

In this discussion we demonstrate that Pit-1 and Oct-1 proteins are capable of forming a heteromeric complex on Pit-1 response elements and that these POU-domain proteins interact in the absence of DNA by a mechanism dependent on the POU homeo domain. Consistent with these data, both Oct-1 and Pit-1 proteins induce the expression of reporter constructs under control of a Pit-1 response element, and we find that these proteins appear to interact simultaneously with the transcriptional apparatus to exert a synergistic effect on both this isolated element and on prolactin gene transcription. Thus, the interaction of Pit-1 and Oct-1 illustrates a system in which a tissue-specific and widely expressed transcription factor can specifically interact, and may effect the expression of a tissue-specific gene.

\section{Results}

Pit-1 and Oct-1 proteins can simultaneously occupy the Prl-1P Pit-1 response element

The enhancer and promoter regions of the prolactin gene each contain four consensus-binding sites for the Pit-1 protein that are individually capable of mediating transactivation by Pit-1 (Fig. 1A; Nelson et al. 1988; Mangalam et al. 1989|. The highest-affinity Pit-1-binding site in the rat prolactin gene is that most proximal to the TATAAA box in the promoter (Prl-1P, Fig. $1 \mathrm{~A}, \mathrm{~B})$. Because Oct-1 was shown previously to bind to the Prl-1P site (Elsholtz et al. 1990), interactions between Pit-1 and Oct-1 were assessed by using this element. In the initial series of experiments, Oct-1-containing protein extracts derived from HeLa cells were mixed with bacterially expressed Pit-1 protein, purified to near homogeneity in the presence of a radiolabeled Prl-1P oligonucleotide, and subjected to mobility-shift analysis. The presence of Oct-1 or Pit-1 proteins in these complexes was demonstrated by the specific reaction of these complexes with antisera specific for Oct-1 or Pit-1 proteins. Under the conditions used here (see Materials and methods) both antisera resulted largely in the specific inhibition of complex formation. As shown in lane 1 of Figure 1C, incubation of purified Pit-1 with the Prl-1P oligonucleotide led to the formation of two complexes designated $\mathrm{C}_{1}$ and $\mathrm{C}_{2}$, which have been shown by previous analyses to represent Pit-1 monomeric $\left(\mathrm{C}_{1}\right)$ and homodimeric $\left(\mathrm{C}_{2}\right)$
Figure 1. Binding of Pit-1, Oct-1, and Pit1: Oct-1 heterodimers to the Prl-1P cisacting element. $(A)$ Schematic of the distal enhancer and proximal promoter of the rat prolactin gene. The positions of the Prl-1P element and other similar elements are shown as black boxes, and the position of an estrogen response element (ERE) in the distal enhancer is indicated. $(B)$ Sequences of the naturally occurring prolactin (Prl$1 \mathrm{P})$ and mutant $\operatorname{Prl}-1 \mathrm{P}\left(\mathrm{AT}_{\text {mut }}\right)$ Pit1-binding site oligonucleotides used in these experiments. $(C$ and $D)$ Binding of Pit-1, Oct-1, and Pit-1: Oct-1 heteromers to the Prl-1P element $(C)$, and the $\mathrm{AT}_{\text {mut }}$ element $(D)$. Each panel contains the results of experiments in which purified Pit1, HeLa cell nuclear extract, or a mixture of purified Pit-1 protein and HeLa cell nuclear extract (as indicated at the top of $C$ and $D$ ) were incubated with 10 fmoles of the indicated DNA-binding site and fractionated on a nondenaturing gel. Also included in each reaction /as indicated at the top of $C$ and $D$ ) were antisera specific for Pit-1 or Oct-1. The positions of Pit-1, Oct1 , and Pit-1/Oct-1 protein-DNA complexes are given at the right of each panel. Lanes containing Oct-1 antiserum contain a faint species approximately in the position of the Oct-1-Prl-1P complex, probably due to a protein in the unfractionated antiserum.

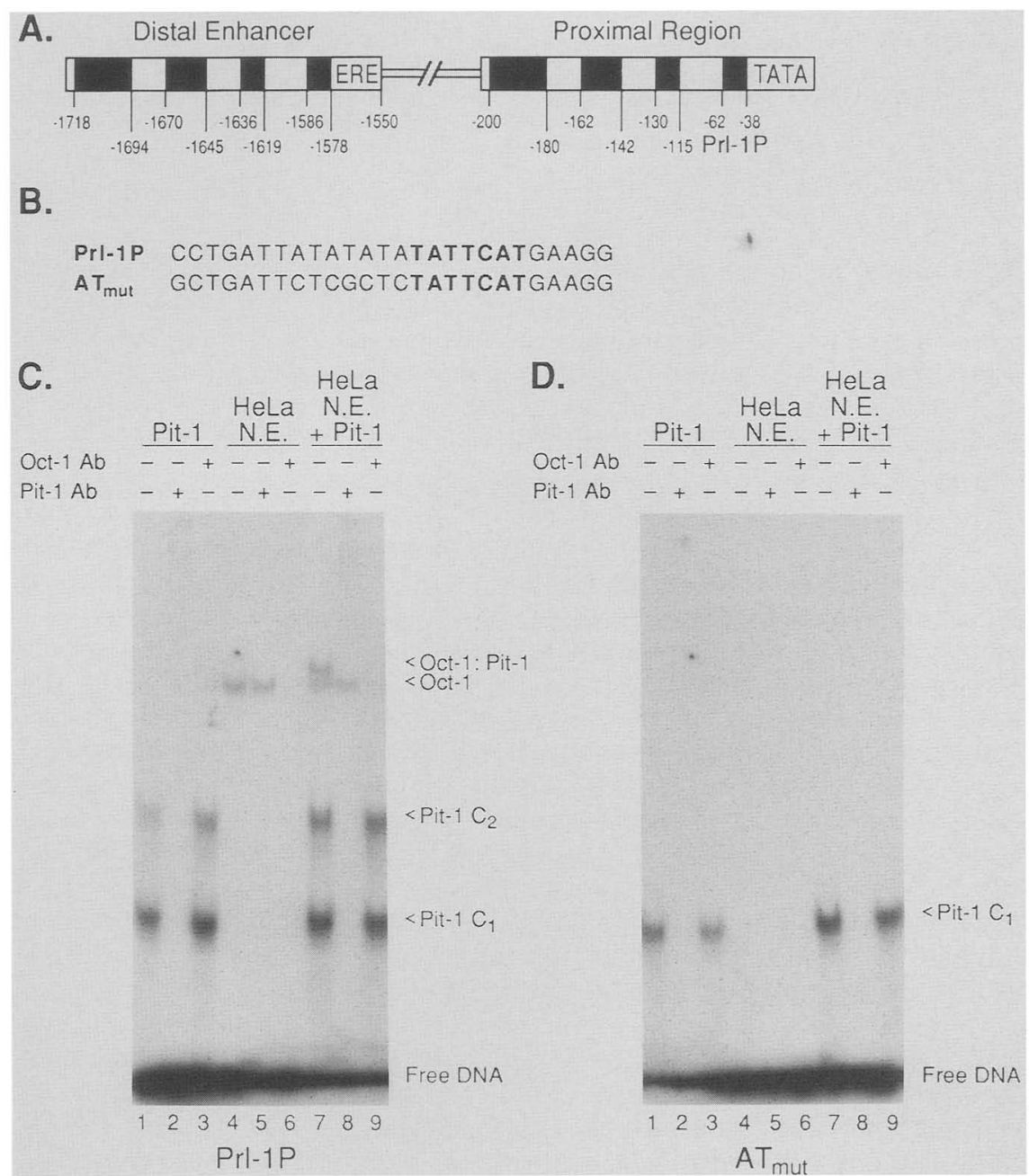


complexes (Ingraham et al. 1990). Each of these complexes contained Pit-1 protein, as demonstrated by their reaction with antiserum specific for Pit-1 (Fig. 1C, lane 2). Antiserum specific for Oct-1 failed to react with either of the complexes (Fig. 1C, lane 3). When HeLa cell nuclear extract alone was incubated with the Prl-1P probe (Fig. 1C, lane 4), a single, Oct-1-containing protein-DNA complex formed (Elsholtz et al. 1990). The presence of Oct-1 in this protein-DNA complex was confirmed by reaction of the complex with Oct-1 antiserum (generous gift of T. Kristie; Kristie et al. 1989; Fig. 1C, lane 6). The reaction was specific to Oct-1 because Pit-1 antiserum (Fig. 1C, lane 5) exerted no effect on the formation or mobility of the complex. However, when purified Pit-1 protein and the Oct-1-containing HeLa cell nuclear extract were mixed and then incubated with Prl$1 \mathrm{P}$ oligonucleotide, the mobility of the Oct-1-containing protein-DNA complex was retarded in the gel (Fig. 1C, lane 7). Both Pit-1 (lane 8) and Oct-1 (lane 9) antisera resulted in the elimination of this complex from its normal position in the gel, demonstrating that both Pit-1 and Oct- 1 together bound the Prl-1P element leading to the formation of a higher-order complex. To determine the specificity of Oct-1 binding and heteromer formation on the Prl-1P site, we used $\mathrm{AT}_{\text {mut }}$ a mutated form of the Prl-1P site (Fig. 1B). Experiments similar to those described above indicated that Pit-1 was capable of binding primarily as a monomer to the $\mathrm{AT}_{\text {mut }}$ site (Fig. $1 \mathrm{D}$; V. Albert, unpubl.). Oct-1 protein was found to be incabable of binding to the site alone or as a complex with Pit-1 protein. On the basis of these results it appears that the AT-rich sequences immediately $5^{\prime}$ of the consensus TATNCAT Pit-1-binding site represent an essential determinant of Oct-1 binding.

\section{Pit-1 and Oct-1 interact in binding to the Prl-1P element}

The demonstration that complexes containing both Pit-1 and Oct-1 could form on the Prl-1P-binding site raised the question of whether these proteins contacted each other in the higher-order complex. To investigate this question, Pit-1 and Oct-1 proteins were chemically cross-linked while simultaneously bound to the Prl-1Pbinding site. As shown in Figure 2A, the formation of a cross-linked species was clearly dependent on the presence of both Pit-1 and Oct-1 proteins in the DNA-binding reaction, because a cross-linked species did not arise if Pit-1 was omitted (lane 2) or if an equal mass of another DNA-binding protein [cAMP response elementbinding (CREB) protein, lane 4)] was included in the cross-linking reaction. The cross-linked species migrated as a series of bands with a relative molecular mass of $\sim 160 \mathrm{kD}$, or $30 \mathrm{kD}$ larger than the predicted mass of 130 $\mathrm{kD}$.

This aberrance, as well as the heterogeneity of the species, may reflect the inability of the cross-linked species to assume a random coil configuration due to the presence of covalent linkage(s) between proteins. Thus, it is not possible to determine unambiguously the stoichiometry of proteins in the complex by this technique. Because Oct-1 alone on the Prl-1P site did not lead to the formation of a cross-linked species, we conclude that Oct-1 occupies a single site on the Prl-1P element, consistent with the mobility-shift analyses presented above.

To determine whether the formation of a cross-linked species was specific for Prl-1P or Prl-1P-like elements, we performed competition experiments in which a $100-$ fold molar excess of Prl-1P oligonucleotide, $\mathrm{AT}_{\text {mut }}$ oligonucleotide or another AT-rich oligonucleotide, the binding site of the Drosophila fushi tarazu (ftz) gene product, was added to the DNA-binding reactions prior to the addition of cross-linker. As expected, only Prl-1P was effective as a competitor of Oct-1 binding or crosslinked species formation (Fig. 2, lanes 5-8), indicating that specific binding of Oct-1 to the Prl-1P element is required for the formation of the cross-linked species. These data suggest that Pit-1 and Oct-1 proteins uniquely give rise to a cross-linked species and that formation of this cross-linked species is uniquely inhibited by the presence of excess Prl-1P DNA and not by other competitor oligonucleotides. It is interesting to note that other Pit-1-binding sites, such as that most proximal to the TATA box in the growth hormone gene promoter and Pit-1 gene promoters, also bind Pit-1 and Oct-1 as heterodimers (J.W. Voss, unpubl). Other Pit-1-binding sites, such as the distal site in the growth hormone gene promoters are only capable of binding each protein separately (J.W. Voss, unpubl.).

It was of interest to determine whether or not there was a functional consequence of the proximity of bound Pit-1 and Oct-1 proteins on the Prl-1P element or whether their proximity was due to a fortuitous occurrence of two closely spaced binding sites. Because specific interactions between two proximally bound proteins could be manifested as an increase in complex stability or cooperativity (Ptashne 1986), we sought to determine whether Pit-1 protein, bound to the Prl-1P site, could stabilize the association of Oct-1 protein to the binding site. Thus, the relative rates of dissociation of the Pit-1 : Oct-1-DNA and Oct-1-DNA complexes were determined in a competition experiment shown in Figure $2 \mathrm{~B}$. The results demonstrated that the binding of Oct-1 to the Prl-1P site was stabilized by the binding of Pit-1 because the heteromeric complex selectively persisted in the presence of the competitor DNA. Thus, Pit-1 : Oct-1 heteromeric DNA-protein complexes, as well as Pit-1 : Pit-1 homodimers (Ingraham et al. 1990), appear to be stabilized by specific protein-protein interactions.

In a second experiment, the relative preference of Pit-1 for binding sites occupied by Pit-1 monomer or by Oct-1 protein was evaluated in a mobility-shift assay. Purified Pit-1 protein was titrated into reaction mixtures that contained a constant ratio of prebound Oct-1-Prl-1P DNA or, Prl-1P DNA alone. In the absence of Pit-1, a single band of Oct-1-Prl-1P complex was noted (Fig. 2C, lane 7). As purified Pit-1 was titrated into identical Oct1-containing reaction mixtures, the Pit-1 : Oct-1-DNA 
Figure 2. Pit-1 and Oct- 1 interact in binding to the Prl-1P element. $(A)$ Chemical cross-linking of Pit-1 and Oct- 1 on the Prl-1P element. Purified Pit- 1 (1 ng) or CREB ( $1 \mathrm{ng}$ ) was added to DNA-binding reactions that contained ${ }^{35} \mathrm{~S}$-labeled Oct- 1 translated in vitro and biotinylated DNA. Complexes were precipitated using streptavidin-agarose and were chemically cross-linked by incubation in $1 \mathrm{mM} \mathrm{BMH}$. The products of the reaction were fractionated on a denaturing polyacrylamide gel and visualized by fluorography. (Lane 1) ${ }^{14} \mathrm{C}$-Labeled molecular weight standards; (lane 2) a reaction from which Pit-1 was omitted; (lane 3 ) a reaction that contained $1 \mathrm{ng}$ of purified Pit-1; (lane 4) a reaction that contained I ng of purified CREB protein. \{Lanes 5-8) DNA-binding reactions performed in the presence of $100 \times$ molar excess of competing oligonucleotide (as indicated at the top of each lane): (Lane 5) Prl-1P element; (lane 6) the DNA recognition element of the Drosophila $\mathrm{ftz}$ gene product (AATTGTCAAGTAATCGTAAA); (lane 7) $\mathrm{AT}_{\text {mut }}$ element; (lane 8$){ }^{14} \mathrm{C}$-labeled molecular weight standards. Similar results were obtained when glutaraldehyde was used as a cross-linking agent. (B) Off-rate analysis of homomeric Oct1-DNA and heteromeric Pit-1: Oct-1-DNA complexes. A 120- $\mu$ l DNA-binding reaction containing a ratio of purified Pit-1 and Oct-1 (derived from HeLa cell nuclear extract), set to give approximately equal amounts of homomeric Oct-1-Prl-1P and heteromeric Pit-1 : Oct-1-Prl-1P complexes, was challenged with a 1000-fold molar excess of cold Prl-1P probe. Aliquots of $20 \mu \mathrm{l}$ were removed at postchallenge times indicated at the top of each lane and loaded directly onto a continuously running nondenaturing polyacrylamide gel. Pit-1: Pit-1 homodimeric complex $\left(C_{2}\right)$ persisted over the time course, whereas the Pit-1 monomeric complex $\left(C_{1}\right)$ decayed

A.

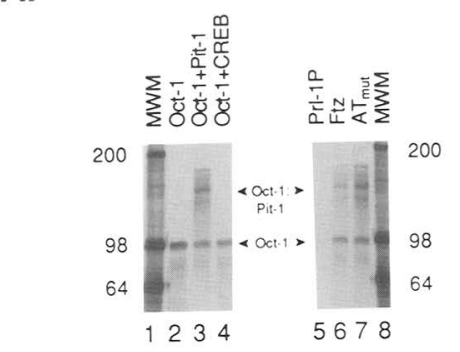

C.
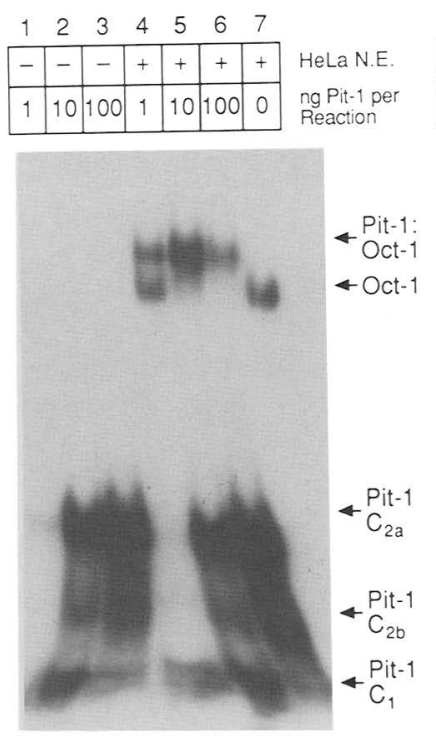

B.

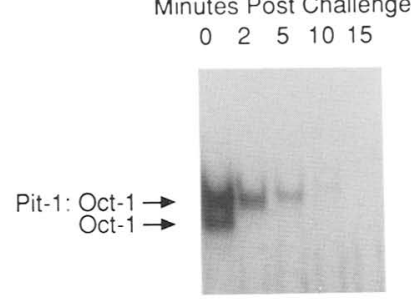

D.

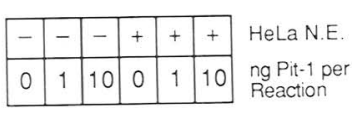

E.

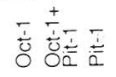

with kinetics similar to that of the Oct-1-Prl-1P DNA complex (data not shown). $(C)$ Extended electrophoresis. Pit-1 : Oct-1 heteromeric complexes form preferentially over Pit-1 : Pit-1 homodimeric complexes. Increasing amounts of purified Pit-1 protein were titrated into reaction mixtures that contained free, ${ }^{35} \mathrm{P}$-labeled Prl-1P probe (lanes 1-3) or Prl-1P probe that was prebound to Oct-1 protein in the reaction mixture (lanes $4-6$ ). The products were fractionated on a nondenaturing polyacrylamide gel and visualized by autoradiography. A reaction that contained prebound Oct-1 but no added Pit-1 is shown in lane 7 . The mass of purified Pit-1 protein added to each reaction is indicated at the top of each lane. The positions of the Pit-1 monomeric and homodimeric complexes are indicated by arrows, as are the positions of Oct-1 homodimeric and Pit-1 : Oct-1 heteromeric complexes. Upon extended electrophoresis, the dimeric complex $\left(\mathrm{C}_{2}\right)$ resolves into two complexes designated $\mathrm{C}_{2 \mathrm{a}}$ and $\mathrm{C}_{2 \mathrm{~b}}$. In situ chemical cross-linking of each of these complexes has determined that both contain Pit-1 molecules that can be cross-linked to form a species of $\sim 64 \mathrm{kD}$ (Ingraham et al. 1990; J.W. Voss and H.A. Ingraham, unpubl.). $(D)$ The results of an experiment similar to that in $C$ but electrophoresed for a shorter period are shown to illustrate the presence of unbound probe in the DNA-binding reactions. The HeLa extract alone results in a gel-shifted species that comigrates with the Pit-1-Prl-1P C 1 , complex. This protein is not Pit-1 (Ingraham et al. 1988; Shöler et al. $1990) .(E)$ Cooperativity of purified, bacterially expressed Oct-1 and Pit-1 proteins in DNA binding. Pit-1 or Oct-1 protein $(0.2 \mathrm{ng})$, or a mixture $\left(0.1 \mathrm{ng}\right.$ of each), was incubated with ${ }^{32} \mathrm{P}$-labeled Prl-1P DNA, as indicated at the top of each lane. After the incubation period the products were fractionated on a nondenaturing polyacrylamide gel. Parallel experiments using $1 \mathrm{ng}$ of each protein separately gave individual Pit-1 or Oct-1 complexes (data not shown).

complex appeared (Fig. 2C, lanes 4-6). At lower concentrations of Pit-1 protein ( $\sim 1 \mathrm{ng} /$ reaction), approximately equimolar amounts of protein-DNA complexes containing either Oct-1 alone or Oct-1 : Pit-1 were detected in the virtual absence of the homodimeric Pit-1-DNA complex $\left(C_{2}\right)$ (Fig. 2C, lane 4). At higher levels of Pit-1 (10 ng/reaction; Fig. 2C, lane 51, all Oct-1 was present as a Pit-1 : Oct-1 complex. At the highest Pit-1 concentrations tested (100 ng/reaction; Fig. 2C, lane 8), however, the Pit-1 : Pit-1-Prl-1p DNA complex appeared to begin to compete with the formation of the Pit-1 : Oct-1-DNA complex. These results indicated that at lower Pit-1 concentrations, formation of the Pit-1 : Oct-1-DNA complex is favored over the formation of the Pit-1 : Pit-1 dimers on DNA. Furthermore, the equilibrium distribution of homo- and heteromeric complexes includes a significant amount of heteromeric complex at Pit-1 concentrations spanning over two orders of magnitude. In the 
experiment shown in Figure 2C, electrophoresis was carried out for an extended period to exaggerate the distance between monomeric and heteromeric complexes. Shown in Figure 2D is a similar experiment electrophoresed for a shorter period of time to verify the presence of unbound DNA probe in the binding reactions.

Because these data suggest that Pit-1 and Oct-1 can exhibit cooperative DNA binding, conditions should exist under which heteromeric complexes could be observed in the absence of detectable formation of Pit-1 or Oct-1 homomeric species alone. To determine whether such conditions existed, we expressed the entire rat Oct1 protein in Escherichia coli as a glutathione-S-transferase (GST) fusion protein to permit purification by glutathione-agarose (Smith and Johnson 1988). The Oct-1coding sequences were obtained from a rat pituitary cDNA library (J.W. Voss, unpubl.) and appeared to vary little from the published sequence of the human gene (Sturm et al. 1988). Pit-1 protein was purified by phosphocellulose chromatography. Preliminary titration experiments were performed to determine the minimal individual protein concentrations required to observe Pit-1 or Oct-1 binding to the Prl-1P probe (data not shown). The results of mixing experiments (Fig. 2E) demonstrate that when combined at concentrations at which neither protein can effect detectable gel shift of the Prl-1P element, these proteins together effectively bind to the Prl1P element (lane 2). To control for the nonspecific effects of increased protein concentration in the mixed reaction, the concentration of DNA-binding protein in reactions containing the isolated proteins was twice that in the mixed reaction (Fig. 2E, $0.2 \mathrm{ng}$ of Oct-1 alone in lane 1; $0.2 \mathrm{ng}$ of Pit-1 alone in lane 3 ).

Thus, three types of experimental evidence support the notion that cooperative interactions occur between Pit-1 and Oct-1 molecules in DNA binding. First, dissociation rate experiments indicated that the Pit-1 : Oct-1 heteromeric complex on Prl-1P DNA was much more stable than the Oct-1-DNA complex alone. Second, Pit1 titration experiments indicated that the binding of Oct- 1 to a Prl-1P element enhanced the subsequent binding of a Pit-1 molecule to the same element relative to an unbound element, or an element occupied by a single Pit-1 molecule. Finally, binding experiments using purified, bacterially expressed Pit-1 and Oct-1 demonstrated that Pit-1 : Oct-1 complex formation can be heavily favored over homomeric complex formation and argue against any possible nonspecific effects of $\mathrm{HeLa}$ cell nuclear extract on binding equilibria. Once bound, the Pit1 : Oct-1 heteromeric complex appears to dissociate from the Prl-1P element faster than the Pit-1 : Pit-1 homodimeric complex (Ingraham et al. 1990), although at equilibrium a significant quantity of heteromeric complex exists in the presence of a wide range of Pit-1 concentrations (Fig. 2C,D, and data not shown). Similar DNA-binding experiments have demonstrated that another POU-domain protein, Brn-3 (He et al. 1989), appears to be incapable of forming heteromeric complexes with either Pit-1 or Oct-1 on the Prl-1P element (R. Gerrero and M.G. Rosenfeld, unpubl.), suggesting that the cooperative binding observed for Pit-1 and Oct-1 to this site is specific for these two POU-domain proteins.

The POU domain is a transferrable domain that is sufficient to mediate an association of POU-domain proteins in the absence of DNA

Because Pit-1 and Oct-1 proteins could form a heteromeric complex on the Prl-1P-binding site, it was of interest to determine whether these proteins could associate directly, in the absence of DNA. In this experiment bacterially expressed Pit-1 protein and ${ }^{35}$-labeled Oct-1 protein translated in vitro were assayed for their ability to interact in solution as determined by coimmunoprecipitation (Materials and methods). As shown in Figure $3 \mathrm{~A}$, the presence of Pit-1 in these binding reactions leads to a dramatic increase in the amount of Oct-1 protein immunoprecipitated by Pit-1 antiserum. The minuscule amount of Oct-1 present in immunoprecipitation in the absence of Pit-1 appears to result from the nonspecific association of the labeled Oct-1 protein with the protein A-Sepharose resin. These data suggest that Pit-1 and Oct-1 can associate in solution.

To substantiate further the interaction of these proteins in the absence of DNA, a protein-protein affinity chromatography technique was employed. A chromatographic resin was constructed by immobilizing a bacterially expressed Pit-l fusion protein consisting of amino acids 104-291 of Pit-1 fused to the carboxyl terminus of the GST protein (Smith and Johnson 1988). This region of Pit-1 encompassed the entire POU domain of Pit-1, which extends from amino acids 121 to 273 . A GST control resin was also constructed by using a fusion protein derived by inserting the same Pit-1-DNA sequences into the bacterial expression vector in the antisense orientation, resulting in the addition of 28 amino acids. In these experiments ${ }^{35}$ S-labeled, in vitro-translated Pit-1, Oct-1, or an unrelated DNA-binding protein, the retinoic acid receptor, were batch-adsorbed to Pit-1 resin or GST control resin and washed with binding buffer, eluted with $0.1 \%$ SDS, and fractionated on a denaturing polyacrylamide gel. The results, shown in Figure 3B, indicated that both Pit-1 and Oct-1 proteins could be associated specifically with the Pit-1 resin but not with the control resin. In contrast, retinoic acid receptor did not appear to associate preferentially with either the Pit-1 resin or the GST control resin.

To map more precisely the portion of the POU domain responsible for the DNA-independent interaction of these proteins, we constructed GST fusion proteins that expressed sequences encompassing the POU-specific domain (amino acids 131-199) or the POU homeo domain (amino acids 210-273) of Pit-1. In these experiments a mixture of ${ }^{35}$ S-labeled, in vitro-translated Pit-1 and Oct1 proteins was incubated with resins that contained the entire POU domain, the POU-specific domain, the POU homeo domain, or the GST control resin described above. After adsorption, the resins were washed extensively with binding buffer and eluted with binding buffer containing increasing $\mathrm{NaCl}$ concentrations. As expected, 
Figure 3. The POU domain is a transferrable domain that is sufficient to mediate the association of POUdomain proteins in the absence of DNA. $(A)$ The POUdomain proteins Pit-1 and Oct-1 can interact in the absence of DNA. ${ }^{35} \mathrm{~S}$-Labeled Oct-1 protein was incubated in the absence (lane 1) or in the presence (lane 2) of purified Pit- 1 protein as described in Materials and methods. The samples were then immunoprecipitated using antiserum specific for the amino terminus of Pit-1, fractionated on an SDS-polyacrylamide gel, and visualized by fluorography. (B) Protein-protein affinity chromatography. Fusion proteins, attached to glutathione-agarose, were prepared as described in Materials and methods. Resins bearing the POU domain of Pit-1 were incubated with ${ }^{35}$ S-labeled Pit-1 (lane 1), Oct-1 (lane 4), or retinoic acid receptor (RAR) (lane 7) under conditions described in Materials and methods. The resins were washed and eluted followed by fractionation of the eluate on a denaturing polyacrylamide gel. Lanes 2,5, and 8 depict the eluates of resins bearing a fusion protein created by ligating the POU-domain insert into the bacterial expression vector in the antisense orientation. Lanes 3,6 , and 9 contain an amount of ${ }^{35} \mathrm{~S}$-labeled protein equal to $10 \%$ of that incubated with the POU domain and control resins. $(C)$ Interaction of POU-domain proteins is mediated by the POU homeo domain. GST fusion proteins expressing the entire POU domain $\left(\mathrm{P}_{\mathrm{S}}+\mathrm{P}_{\mathrm{H}}\right)$, POU-specific domain $\left(\mathrm{P}_{\mathrm{S}}\right)$, POU homeo domain $\left(\mathrm{P}_{\mathrm{H}}\right)$, or a control resin that expressed only the GST protein (control) were batch-adsorbed to a mixture of ${ }^{35} \mathrm{~S}$-labeled, in vitro-translated Pit- 1 and Oct-1 proteins. After adsorption the resins were washed in binding buffer and stepeluted with increasing $\mathrm{NaCl}$ concentrations, as indicated at the top of each lane. The eluates were then fractionated on a denaturing polyacrylamide gel and visualized by fluorography. (LOAD) An amount of ${ }^{35} \mathrm{~S}$ labeled material equal to $10 \%$ of that incubated with each resin.

both Pit-1 and Oct-1 proteins bound to the resin bearing the complete POU domain (Fig. $3 \mathrm{C}$ ), eluting in fractions containing $150-250 \mathrm{~mm} \mathrm{NaCl}$, but they did not bind to the GST control resin. The in vitro-translated Oct-1 and Pit-1 proteins did not bind effectively to the resin bearing the isolated POU-specific domain but clearly bound to the isolated POU homeo domain with an elution profile indistinguishable from that obtained for the complete POU domain.

These experiments provided two independent types of experimental evidence of an interaction between Pit-1 and Oct- 1 proteins in the absence of DNA and indicated that this interaction was likely to be mediated via the POU homeo domain. However, Oct-1 appears not to interact preferentially with either Pit-1 or Oct-1 in the absence of DNA, in contrast to the preferential formation of Pit-1 : Oct-1 heteromeric complexes on the Prl-1P DNA element.

Coexpression of Pit-1 and Oct-1 has a synergistic effect on prolactin gene expression

On the basis of the binding of Pit-1 and Oct-1 to the
Prl-1P cis-active element as heteromers, it was of particular interest to determine whether the coexpression of Pit-1 and Oct-1, in a heterologous cell line, could affect the regulation of the prolactin gene. A series of cotransfection experiments were performed using chimeric reporter constructs that consisted of the distal enhancer and proximal promoter elements of the rat prolactin gene or the Prl-1P element itself fused to the firefly luciferase reporter gene (Nelson et al. 1988; Elsholtz et al. 1990; Crenshaw et al. 1989).

In the first series of experiments designed to test the effect of Oct-1 expression alone on prolactin gene expression, an Oct-1 expression vector consisting of the Oct-1 structural gene fused to the early region enhancer and promoter of human cytomegalovirus (CMV-Oct) was cotransfected with prolactin gene reporter constructs into CV-1 cells. As shown in Figure 4A, transfection of increasing amounts of the Oct-1 expression vector produced a substantial (24-fold) increase in prolactin gene expression. To determine whether the response to Oct-1 could be mediated by the Prl-1P element, we compared the effects of Oct-1 on the expression of constructs that consisted of the minimal prolactin promoter /truncated 
A.
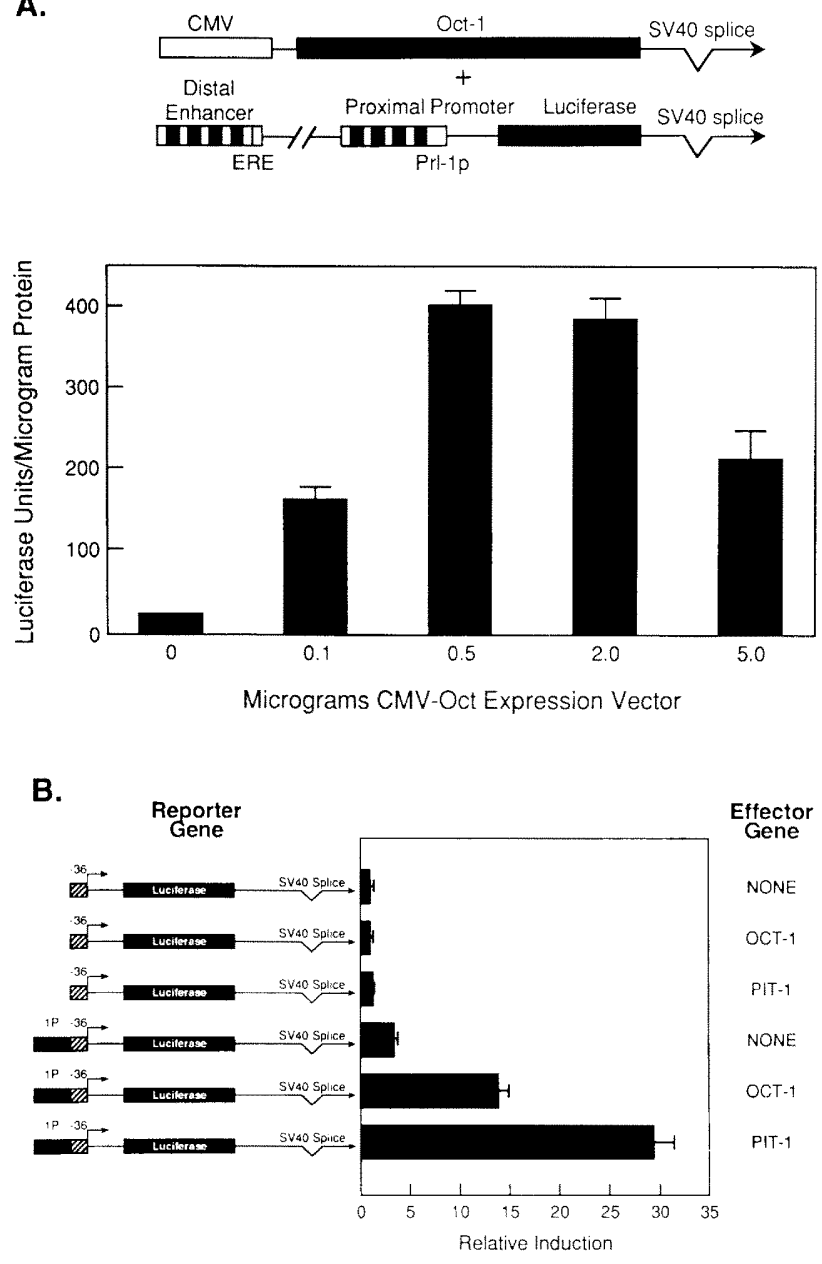

to -36 ) with or without a single Prl-1P element (Fig. 4B). For purposes of comparison, the effect of Pit-1, from an identical expression vector on the expression of these reporter constructs, was measured in parallel. Neither Pit-1 nor Oct-1 exerted a significant effect on the expression of reporter constructs lacking a Prl-1P element (Fig. 4B). However, addition of a single Prl-1P element to the reporter construct enabled the reporter construct to respond to cotransfected Pit-1 and Oct-1 expression vectors. Moreover, the addition of the Prl-1P element to the reporter construct caused a reproducible increase in basal expression level, possibly resulting from the effects of endogenous Oct-1 protein present in CV-1 cells. Consistent with the binding data presented above, transfected Oct-1 did not induce the expression of a reporter gene containing the $\mathrm{AT}_{\text {mut }}$ element substituted for the Prl-1P element (data not shown).

To determine the consequences of the simultaneous expression of Pit-1 and Oct-1 on prolactin gene expression, the CMV-Oct expression plasmid was again used in a series of cotransfection experiments. CMV-Oct-1 11 $\mu \mathrm{g} / \mathrm{ml}$ of $\mathrm{CaPO}_{4}$ precipitate), within the DNA concentration range that produced the maximal effect on prolactin gene expression (see Fig. 4A), was cotransfected with increasing amounts of Pit-1 expression plasmid.
Figure 4. A transfected Oct-1 gene activates the prolactin gene in a site-dependent manner. $(A) \mathrm{A}$ transfected Oct- 1 gene transactivates the prolactin gene distal enhancer and proximal promoter. Schematics of the CMV-Oct-1 effector construct and the prolactin gene reporter construct used in these cotransfection experiments are given at the top. The Oct- 1 plasmid was constructed by fusing the CMV enhancer/promoter to the structural sequences of the Oct- 1 gene as derived from pBSoct- 1 (generous gift of $W$. Herr). The reporter construct consists of a fusion of the distal enhancer $(-1831$ to -1530$)$ and promoter $(-422$ to +33 ) of the rat prolactin gene to the structural sequences of the firefly luciferase gene. Shown graphically is the response of the prolactin gene reporter construct to increasing amounts of Oct1 effector plasmid in CV-1 cells. Each transfection was balanced to contain an equal amount of CMV enhancer by adding CMV expression vector alone. The saturation of prolactin gene expression at the CMV-Oct-1 concentrations shown here proved to be reproducible regardless of the absolute level of reporter gene expression. $(B)$ Oct-1 trans-activation can be mediated through the Prl-1P element. (Left) Schematics of the reporter constructs used in these experiments. These constructs consisted of a single Prl-1P element fused to the rat prolactin gene promoter (position -36 to +33 ), which was, in turn, fused to the structural sequences of the firefly luciferase gene. Control reporter genes were identical in construction but lacked the Prl-1P element. (Right) The effector gene cotransfected with the corresponding reporter gene construct. CMV expression vector alone was substituted for effector plasmids in transfections that did not contain effector genes. Shown in the graph is the relative response of the reporter gene constructs to the corresponding effector plasmids after $\mathrm{CaPO}_{4}$-mediated transfection into $\mathrm{CV}-1$ cells with the basal level activity of the -36 prolactin gene construct equal to 1.0 .

The combination of Pit-1 and Oct-1 trans-activated the prolactin fusion gene to a level two to three times greater than the arithmetic sum of their individual trans-activation levels (Fig. 5A).

To address directly the question of whether Pit-1 and Oct-1 could act together through a single response element, coexpression experiments were performed using a reporter gene that contained a single Prl-1P-binding site per molecule. As shown in Figure 5B, singly transfected Oct- 1 and Pit- 1 expression constructs trans-activated the expression of the Prl-1P reporter construct. Pit-1 and Oct-1 expression constructs failed to trans-activate significantly reporter constructs lacking a Prl-1P element (Fig. 5B). In accord with results using the prolactin promoter/enhancer, induction observed on Prl-1P with the combination of Pit-1 and Oct-1 was 2- to 2.5-fold greater than the arithmetic sum of the stimulation observed for the individually transfected genes (Fig. 5B).

Because the observed inductions for both the prolactin promoter and the isolated Prl-1P element were consistently much greater than the arithmetic sum of the actions of the two individual activities, it appeared that these proteins were acting in concert, as opposed to simply filling unbound sites on separate target genes. Because the majority of sites would be expected to be 
Figure 5. Synergistic effects of Pit-1 and Oct-1 coexpression on prolactin gene expression. (A) Schematics of the Pit-1 and Oct-1 effector plasmids and the distal enhancer/proximal promoter prolactin gene reporter construct are shown at top. Details of the Oct-1 effector plasmid and prolactin reporter construct are given in the legend to Fig. 4. In these experiments a constant amount of Oct- 1 effector plasmid $(1.0 \mu \mathrm{g}$, saturating as shown in Fig. 4A) and prolactin gene reporter construct were cotransfected into CV-1 cells with increasing amounts of a Pit-1 expression plasmid. Each transfection was balanced to contain an equal amount of CMV enhancer by adding CMV expression vector alone. Depicted graphically is the response of the prolactin reporter to transfected Pit-1 or to cotransfected Pit-I and Oct-1 expression plasmids as indicated. (Arithmetic sum) The calculated sum of the responses of the reporter construct to Oct- 1 and Pit- 1 expression plasmids transfected separately. $|B|$ Transcriptional synergism is mediated through a single Prl-1P element. (Left) Schematics of the reporter constructs used in these experiments. The reporter constructs consisted of a single Prl-1P element fused to Prl-1P (position -36 to +33 ) which was, in turn, fused to the structural sequences of the firefly luciferase gene. Control reporter genes were identical in construction but lacked the Prl-1P element. (Right) The effectorgene cotransfected with the corresponding reporter gene construct. In each case, $2 \mu \mathrm{g}$ of effector plasmid was used with $5 \mu \mathrm{g}$ of reporter construct. Each transfection was balanced to contain an equal amount of CMV enhancer by adding CMV expression vector alone. Shown in the graph is the response of each reporter gene construct to the corresponding effector gene measured in luciferase units per microgram of protein. The top and bottom panels show one of three similar experiments, with each point determined in triplicate. Independent experiments have determined that neither Pit-1 nor Oct-1 expression plasmids significantly affected the expression of a CMV-luciferase reporter construct. Error bars indicate the S.E.M for each determination.

bound with Pit-1 homodimers, the ability to record a 2to 2.5 -fold synergism over the assay background suggests a more striking transcriptional effect on those sites harboring heterodimers.

\section{Discussion}

As larger numbers of transcription factors have been defined, it has become apparent that a greater diversity of gene expression can be provided by a combinatorial code in which functional heteromers exert differential transcriptional effects on subsets of recognition elements (Glass et al. 1989). The POU-domain gene family represents a large family of transcription factors, and interactions between members of this gene family expressed in an overlapping temporal and spatial pattern might provide additional specificity of gene activation. In this discussion we have demonstrated that the POU-domain proteins Pit-1 and Oct-1 can interact to form a heteromeric complex on a DNA-binding site. When coex-
A.
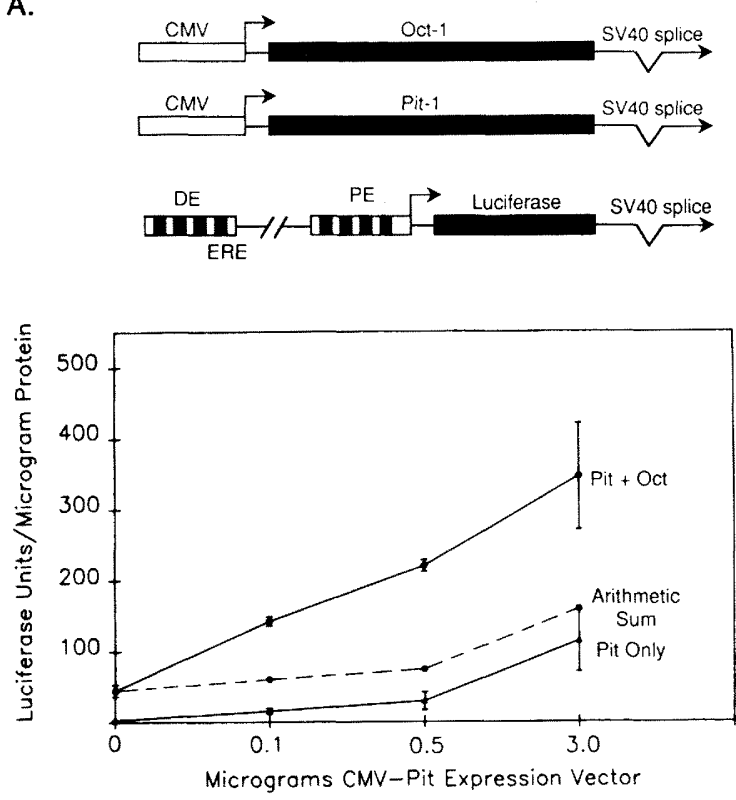

B.

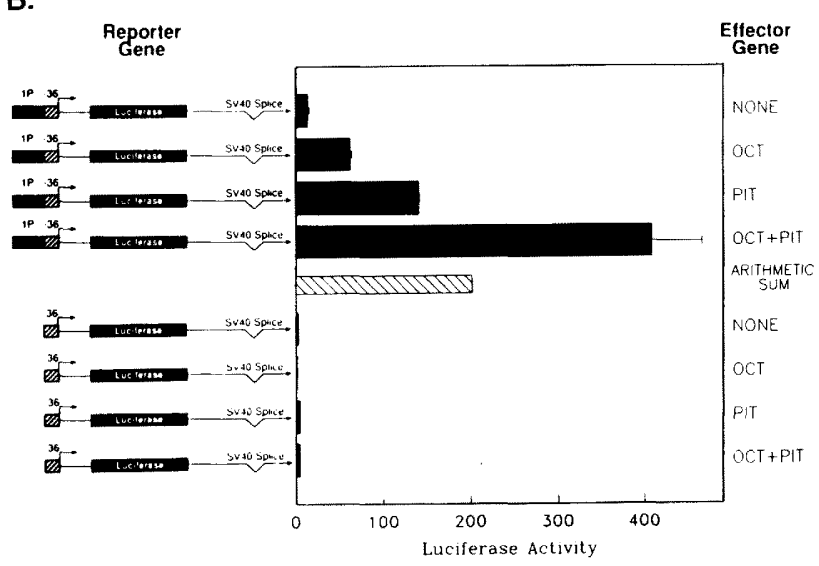

pressed in cells, these two proteins can cooperate in trans-activating the expression of a pituitary-specific gene to levels greater than those observed when the proteins are expressed separately. Thus, the POU-domain gene family may exhibit a complex array of heterodimers analogous to proteins of the leucine zipper (Landschulz et al. 1988; Rauscher et al. 1988; Cohen et al. 1989; Hai et al. 1989), steroid receptor (Glass et al. 1989, 1990), and helix-loop-helix (Murre et al. 1989a,b) families.

\section{Association of POU-domain proteins}

The formation of homo- and heteromeric protein complexes of POU-domain proteins on DNA-binding sites illustrates a means by which targeting of these transactivators to specific genes may be regulated. Cooperation among POU-domain proteins may not only modify the number and type of genes targeted but may also produce quantitatively distinct effects on those sites that are recognized. Thus, the data presented here demon- 
strate that Pit-1 can stabilize the binding of Oct-1 to an element in the prolactin gene regulatory region and that Pit-1 appears to associate preferentially with elements bound by Oct-1. Under appropriate conditions the binding of these proteins appears to be codependent, although we do not precisely know the relative thermodynamic contributions of protein-protein and protein-DNA interactions to homo- and heterodimer formation. The formation of heteromeric species between Oct-1 and Pit-1 was not entirely unexpected, as two other reports document the cooperative nature of homodimer formation in DNA binding between Pit-1 molecules (Ingraham et al. 1990) and between Oct-2 molecules (Lebowitz et al. 1989).

The interaction of Pit-1 and Oct- 1 on the Prl-1P element is clearly specific. Although Oct-1 binds to this element alone and in conjunction with Pit-1, no evidence of Oct-1 : Oct-1 interactions could be detected. This is in contrast to Pit-1, which is capable of both homo- and heterodimeric interactions on the Prl-1P site. Recent data demonstrating that the POU-domain protein Brn-3 does not form heterodimeric complexes with either Pit-1 or Oct-1 on the Prl-1P element (R. Gererro and M.G. Rosenfeld, unpubl.) support the notion that the interaction of Pit-1 and Oct-1 is specific and that the Prl-1P element is not simply an element that promiscuously binds available POU-domain proteins. Furthermore, previously reported experiments using chimeric proteins have demonstrated that Pit-1 molecules bearing the Oct-1 POU domain bind to the Prl-1P element as monomers (Ingraham et al. 1990).

Our analysis of interactions between POU-domain proteins in the absence of DNA did not reveal a marked preference of Pit-1 for Oct-1 as did our analysis of interactions in the presence of a specific DNA-binding site. Therefore, it is likely that the affinity observed between these proteins in the absence of DNA may reflect an interaction distinct from that observed when the two proteins are bound to the Prl-1P DNA element. Although specific, the interaction described here appears to be relatively weak based on the elution profile of proteins from the protein-protein affinity columns. This is consistent with the previous observation that Pit- $1 \mathrm{~mol}$ ecules are not readily cross-linked in the absence of DNA (Ingraham et al. 1990). Recent evidence indicates, however, that other POU-domain proteins are capable of much stronger interactions in the absence of DNA, leading in this case, however, to an inhibition of DNA binding (M. Treacy et al. 1991). Indeed, variations in the relative affinity of dimeric transcription factors for each other have been described in other systems and are likely to provide a level of gene regulation (Hai et al. 1989).

Trans-activation by Oct-1 and Pit-1 : Oct-1 in pituitary-specific gene expression

The results presented here provide evidence for the simultaneous interaction of Pit-1 and Oct-1 proteins with the transcriptional apparatus and illustrate that one consequence of their interaction can be the regulation of prolactin gene expression. An unexpected observation was that Oct-1 alone is capable of trans-activating the expression of the prolactin gene. Reports by other investigators (Tanaka and Herr 1990) using a similar Oct-1 expression vector indicated that Oct-1 was unable to affect the expression of a $\beta$-globin reporter construct fused to Oct-1-binding sites. The source of this difference may lie, for example, in the types of cells used or the amounts of effector and target genes used. Other reports indicate that Oct- 1 can trans-activate reporter constructs bearing octamer-binding sites (Kristie and Roizman 1984; Dreyfus et al. 1987; Wirth et al. 1987; LeBowitz et al. 1989; Johnson et al. 1990; Kemler et al. 1990), and it has been suggested that the quantitatively low level of octamer site-dependent transcription observed in non-B cells may stem from quantitatively low levels of Oct-1 present in these cells as well as the affinity of the octamer-binding site for the octamer protein (LeBowitz et al. 1989; Kemler and Schaffner 1990; Kemler et al. 1990).

Because the coexpression of Pit-1 and Oct-1 was capable of producing levels of trans-activation two- to threefold higher than the sum of the levels observed when these POU-domain proteins were expressed separately, we conclude that these proteins may exert quantitatively different transcriptional effects when bound as heteromers. This conclusion is reinforced by our observation that the synergistic effect is reproducible when using reporter constructs regulated by a single Prl-1Pbinding site, a DNA element on which Pit-1 and Oct-1 proteins bind as heterodimers and can be chemically cross-linked in vitro. The degree of synergism observed here is likely to be underestimated for two reasons. First, because Oct- 1 is present constituitively in the untransfected cell, it is likely to contribute to the induction observed when Pit- 1 alone is expressed. Second, the fraction of reporter genes bound by heteromeric complexes at equilibrium will be only a fraction of all bound reporter genes, diluting the potential effect of a purely heteromeric population. Because of these considerations the transcriptional efficacy of Pit-1 : Oct-1 heteromers on the Prl-1P element would appear to be much greater than Pit-1 homodimers bound to the same site. These data are comparable to effects observed previously in the case of thyroid hormone receptor and retinoic acid receptor heterodimers (Glass et al. 1989) and argue that Pit-1 : Oct-1 heteromers can potentially serve to modulate transcriptional responses in the anterior pituitary gland.

Oct-1 protein appears to be expressed much earlier during pituitary development than Pit-1, and analysis of extracts prepared from embryonic rat pituitary glands provides evidence of the formation of Pit-1 : Oct-1 heteromeric molecules in cells of the developing pituitary (J.W. Voss, unpubl.) It is therefore possible that the presence of Oct-1 protein in developing pituitary cells may make the Pit-1 gene (Chen et al. 1990) or prolactin promoters "hypersensitive" to minuscule amounts of Pit-1 protein, resulting in a rapid induction of these genes shortly after the onset of Pit-1 translation. Hence, the observation that Pit- 1 is preferentially incorporated into Pit-1 : Oct-1 heteromers rather than Pit-1: Pit-1 ho- 
modimers on the Prl-1P element is relevant in this context. Experiments to determine the role of heteromeric POU-domain proteins in the establishment of pituitaryspecific gene expression are currently under way.

\section{Materials and methods}

DNA-binding reactions and mobility-shift analysis

DNA-binding reactions were carried out in a buffer consisting of $50 \mathrm{mM} \mathrm{KCl}, 20 \mathrm{~mm}$ HEPES (pH 7.8), $1 \mathrm{~mm} \mathrm{MgCl}_{2}, 0.1 \% \mathrm{NP}-40$, $5 \mathrm{mM}$ DTT, $10 \%$ glycerol, $5 \mu \mathrm{g} / \mathrm{ml}$ of poly[d(I-C)], and $0.5 \%$ nonfat dry milk. Reaction times were for $10 \mathrm{~min}$ unless otherwise indicated. Where applicable, Pit-1 or Oct-1 antiserum (Kristie et al. 1989) was incubated with proteins prior to the addition of labeled DNA. When incubated with proteins prior to the addition of DNA probe, at the concentrations used $11: 200$ final dilution), each antiserum results in a significant reduction in the formation of cognate DNA-protein complex but not other DNA-protein complexes (see Fig. 1). The major epitope recognized by anti-Oct-1 serum lies in the POU domain (Kristie et al. 1989). The major epitope recognized by the anti-Pit-1 serum lies between amino acids 50 and 100 of the Pit- 1 -coding sequence, and the serum does not detectably react with either the Pit-1 or Oct-1 POU domain. Both sera were generated in New Zealand white rabbits. Electrophoresis was carried out on a $4 \%$ polyacrylamide gel in $0.5 \times \mathrm{TBE}$ buffer at $10 \mathrm{~V} / \mathrm{cm}$ for $\sim 2.5$ $\mathrm{hr}$. In some cases, sodium acetate was added to the anode for a final concentration of $1 \mathrm{M}$ after $2 \mathrm{hr}$ of electrophoresis, to prevent unbound probe from leaving the gel. Typically 10-50 fmoles of oligonucleotide probe were used in the DNA-binding reactions.

\section{Chemical cross-linking reactions}

Chemical cross-linklng reactions were carried out essentially as described by Glass et. al. (1989). Briefly, $\left[{ }^{35}\right.$ S|methioninelabeled, in vitro-translated Oct-1 protein was incubated with biotinylated Prl-1P oligonucleotide in the presence or absence of competitor oligonucleotides (e.g., FTZ or $\mathrm{AT}_{\text {mut }}$ ) or purified Pit-1 or CREB proteins. After the incubation, the complexes were precipitated using streptavidin-agarose resin (BRL), washed extensively to remove unbound molecules, and incubated for $1 \mathrm{hr}$ in $1 \mathrm{~mm}$ bis-maleinidohexane (BMH). Similar results were obtained when glutaraldehyde was substituted as a cross-linker.

\section{Pit-1 and Oct-1 protein preparation}

Pit-1 protein was expressed as described previously (Studier and Moffat 1986) in the bacterial strain BL21(DE3) using the expression vector $\mathrm{pET} 3 \mathrm{a}$ (Studier and Moffat 1986). Pit-1 was prepared from bacterial lysates essentially as described by Hoey and Levine (1988), followed by continuous gradient elution phosphocellulose chromatography. The fraction used in this study was judged to be $\sim 90 \%$ pure. Oct-1 protein was prepared by in vitro translation in the presence of $\left[{ }^{35} S\right]$ methionine, with capped RNA derived from HindIII-digested pBScot-1 (generous gift of W. Herr) transcribed in vitro using T7 RNA polymerase. The Oct-1-GST fusion expression vector used here was constructed by fusing the entire rat Oct-1-coding sequence (starting at the first methionine codon of the coding sequence) to the carboxyl terminus of the GST protein (Smith and Johnson 1988). The purification of the fusion protein from $E$. coli extracts was essentially as described below. Oct-1 was $>91 \%$ homogenous, as estimated by staining of SDS-polyacrylamide gel-fractionated protein (Laemmli 1970).

\section{Coimmunoprecipitation assays}

Pit-1 or Oct-1 antiserum was first incubated with protein ASepharose $(300 \mu l / 100 \mu l$ of resin) in phosphate-buffered saline followed by extensive washing. Antibody-bound resin was then incubated in the presence of bacterially synthesized Pit- 11300 $\mathrm{ng} / 100 \mu \mathrm{l}$ of resin) for $2 \mathrm{hr}$ at $4^{\circ} \mathrm{C}$ in a buffer that consisted of $0.2 \%$ sodium deoxycholate, $0.1 \% \mathrm{NP}-40,100 \mathrm{mM} \mathrm{NaCl}, 20 \mathrm{~mm}$ HEPES (pH 7.8), and 5 mM DTT. Unbound Pit-1 was washed away, and the resin was incubated with in vitro-translated Oct1 in the same buffer without deoxycholate for $20 \mathrm{~min}$ on ice. Unbound Oct-1 was washed away, and bound Oct-1 eluted with $1.0 \%$ SDS.

\section{Protein-protein affinity chromatography}

Protein fusions were made using the pGEX vector system (Pharmacia). The fusion proteins were expressed and purified essentially as described elsewhere (Smith and Johnson 1988). Briefly, E. coli harboring the expression vector was induced with $0.1 \mathrm{~mm}$ IPTG and harvested $3 \mathrm{hr}$ later. The bacteria were lysed by treating with $3 \mathrm{mg} / \mathrm{ml}$ of lysozyme for $10 \mathrm{~min}$ at $4^{\circ} \mathrm{C}$ and adding Tween-20 and Triton X-100 to a final concentration of $0.1 \%$ (vol/vol). Insoluble material was removed by centrifugation, and the supernatant was subsequently incubated with glutathioneagarose (Sigma) for $1 \mathrm{hr}$ at $4^{\circ} \mathrm{C}$. The beads were washed with lysis buffer and stored at $4^{\circ} \mathrm{C}$. Before use, resins were washed twice in a buffer that consisted of $50 \mathrm{mM} \mathrm{KCl}, 20 \mathrm{mM}$ HEPES (pH 7.8), 2 mM EDTA, 0.1\% NP-40, 5 mM DTT, 10\% glycerol, and $0.5 \%$ nonfat dry milk. Pit- 1 and control resins $\{10 \mu l$ packed volume), bearing equal masses of fusion protein as determined by Coomassie blue staining, were batch-adsorbed for $30 \mathrm{~min}$ with intermittent agitation to ${ }^{35} \mathrm{~S}$-labeled proteins in $100 \mu \mathrm{l}$ of the buffer described above. The resins were then washed three times in $1.5 \mathrm{ml}$ of binding buffer. The degree to which POUdomain/POU-domain interactions occur between fusion proteins bound to the resin was not determined. The ability of the Pit-1 resin to bind stably and specifically to the Prl-1P element as well as the glutathione residues of the agarose beads indicated that this fusion protein had adopted a "native" conformation that was not disrupted during the purification procedure (J.W. Voss, unpubl.).

\section{Transient cotransfection analysis}

African green monkey kidney cells (CV-1) were plated at a density of $2 \times 10^{5}$ cells per $60-\mathrm{mm}$ plate in Dulbecco's modified Eagle medium supplemented with $10 \%$ newborn calf serum. One day later each dish of cells was transfected with $1.7 \mu \mathrm{g}$ of reporter construct with the indicated amounts of Oct-1 or Pit-1 expression vector using the calcium phosphate technique (Chen and Okayama 1987). Expression vector concentrations are given in the figures as micrograms of vector/ $1 \mathrm{ml}$ of calcium phosphate precipitate. Each milliliter of precipitate was divided equally among three replicate dishes of cells. The transfected cells were harvested $48 \mathrm{hr}$ after transfection and assayed for luciferase activity as described previously (de Wet et al. 1987). The values plotted in Figure 4 represent the average of the three replicate dishes, and the data shown are representatives of at least three identical experiments. When the CMV-Oct transfection experiments presented here were repeated in HeLa cells, induction of our reporter construct was still observed but the fold induction was much lower (6- vs. 24-fold; data not shown). 
As shown in Figure 4, a titration curve of Oct-1 expression vector indicates that there is an optimal level of Oct-1 required for maximal induction of our reporter construct.

\section{Acknowledgments}

We are especially grateful to Dr. Holly Ingraham and Dan Drolet for providing reagents and useful discussion. We also thank Drs. Ron Emeson, E. Bryan Crenshaw III, Vivian Albert, Alan Wells, Mark Adler, and Christopher Glass for careful review of the manuscript and useful discussions, and Chuck Nelson for maintenance and aid in tissue culture experiments. We are particularly grateful to Dr. Winship Herr, Dr. Thomas Kristie, Dr. Michael Mathis, and Steven Lipkin for providing reagents. These studies were supported by a grant from the National Institute of Diabetes and Digestive and Kidney Diseases (NIDDK) (National Institutes of Health 2R01 DK18477). J.W.V. is an American Cancer Society fellow (PF-3407); M.G.R. is an investigator with the Howard Hughes Medical Institute.

The publication costs of this article were defrayed in part by payment of page charges. This article must therefore be hereby marked "advertisement" in accordance with 18 USC section 1734 solely to indicate this fact.

\section{References}

Bodner, M., J.L. Castrillo, L.E. Theill, T. Deerinck, M. Ellisman, and M. Karin. 1988. The pituitary-specific transcription factor GHF-1 is a homeobox-containing protein. Cell 50: 267275.

Burglin, T.R., M. Finney, A. Coulson, and G. Ruvkun. 1989. Caenorhabditis elegans has scores of homeobox-containing genes. Nature 341: 239-243.

Cao, Z., E.A. Barron, and Z.D. Sharp. 1988. Prolactin upstream factor I mediates cell-specific transcription. Mol. Cell. Biol. 8: $5432-5438$.

Chen, C. and H. Okayama. 1987. High efficiency transformation of mammalian cells by plasmid DNA. Mol. Cell. Biol. 7: 2745-2752.

Chen, R., H.A. Ingraham, M.N. Treacy, V.A. Albert, L. Wilson, and M.G. Rosenfeld. 1990. The pituitary POU-domain protein Pit-1 can positively and negatively regulate transcription of its own promoter. Nature 346: 583-586.

Cohen, D.R., C.P. Ferreira, R. Gentz, B.R. Franza, and T. Curran. 1989. The product of a fos-related gene, fra-I, binds cooperatively to the AP-1 site with Jun: Transcription factor AP-1 is comprised of multiple protein complexes. Genes \& Dev. 3: $173-184$.

Clerc, R.G., L.M. Corcoran, J.H. LeBowitz, D. Baltimore, and P.A. Sharp. 1988. The B-cell-specific Oct-2 protein contains POU box- and homeo box-type domains. Genes \& Dev. 2: 1570-1581.

Crenshaw, E.B. III, K. Kalla, D.M. Simmon, L.W. Swanson, and M.G. Rosenfeld. 1989. Cell-specific expression of the prolactin gene in transgenic mice is controlled by synergistic interactions between promoter and enhancer elements. Genes \& Dev. 3: 959-972.

Davis, D.L, P.-F. Cheng, A.B. Lassar, and H. Weintraub. 1990. The MyoD DNA binding domain contains a recognition code for muscle-specific gene activation. Cell 60: 733-746.

de Wet, J.R., K.V. Wood, M. deLuca, D.R. Helinski, and S. Subramani. 1987. Firefly luciferase gene: Structure and expression in mammalian cells. Mol. Cell. Biol. 7: 725-737.

Dreyfus, M., N. Doyen, and F. Rougen. 1987. The conserved decanucleotide from the immunoglobulin heavy-chain pro- moter induces a very high transcriptional activity in B-cell when introduced into an heterologous promoter. $E M B O$. I. 6: $1685-1690$.

Eisholtz, H.P., V.R. Albert, M.N. Treacy, and M.G. Rosenfeld. 1990. A two-base change in a POU factor-binding site switches pituitary-specific to lymphoid-specific gene expression. Genes \& Dev. 4: 43-51.

Finney, M., G. Ruvkin, and H.R. Horvitz. 1988. The C. elegans cell lineage and differentiation gene unc- 86 encodes a protein containing a homeodomain and extended sequence similarity to mammalian transcription factors. Cell 55: 757769.

Fox, S.R., M.T.C. Jong, J. Casianover, S.F. Ye, F. Stanley, and H.H. Samuels. 1990. The homeodomain protein, Pit-1/GHF1 , is capable of binding to and activating cell-specific elements of both the growth hormone and prolactin gene promoters. Mol. Endocrinol. 4: 1069-1080.

Glass, C.K, S.M. Lipkin, O.V. Devary, and M.G. Rosenfeld. 1989. Positive and negative regulation of gene transcription by a retinoic acid/thyroid hormone receptor heterodimer. Cell 59: 697-708.

Glass, C.K., O.V. Devary, and M.G. Rosenfeld. 1990. Multiple cell type-specific proteins differentially regulate target sequence recognition by the $\alpha$ retinoic acid receptor. Cell 63: 729-738.

Hai, T., L. Fang, W.J. Coukos, and M.R. Green. 1989. Transcription factor ATF cDNA clones: An extensive family of leucine zipper proteins able to selectively form DNA-binding heterodimers. Genes \& Dev. 3: 2083-2090.

He, X, M.M. Treacy, D.M. Simmons, H.A. Ingraham, L.W. Swanson, and M.G. Rosenfeld. 1989. Expression of a large family of POU-domain regulatory genes in mammalian brain development. Nature 340: 35-42.

Herr, W., R.A. Sturm, R.G. Clerc, L.M. Corcoran, D. Baltimore, P.A. Sharp, H.A. Ingraham, M.G. Rosenfeld, M. Finney, G. Ruvkin, and H.R. Horvitz. 1988. The POU domain: A large conserved region in the mammalian pit-1, oct-1, oct- 2 , and Caenorhabditis elegans unc-86 gene products. Genes \& Dev. 2: 1513-1516.

Hoey, T. and M. Levine. 1988. Divergent homeobox proteins recognize similar DNA sequences in Drosophila. Nature 332: 858-861.

Ingraham, H.A, R. Chen, H.J. Mangalam, H.P. Elsholtz, S.E. Flynn, C.R. Lin, D.M. Simmons, L. Swanson, and M.G. Rosenfeld. 1988. A tissue-specific transcription factor containing a homeodomain specifies a pituitary phenotype. Cell 55: 519-529.

Ingraham, H.A, S.E. Flynn, J.W. Voss, V.R. Albert, M.S. Kapiloff, L. Wilson, and M.G. Rosenfeld. 1990. The POU-specific domain of Pit-1 is essential for sequence-specific, high affinity DNA binding and DNA-dependent Pit-1 -Pit-1 interactions. Cell 81: 1021-1033.

Johnson, D.G., L. Carayannopoulos, J.D. Capra, P.W. Tucker, and J.H. Hanke. 1990a. The ubiquitous octamer-binding protein(s) is sufficient for transcription of immunoglobulin genes. Mol. Cell Biol. 10: 982-990.

Johnson, W.A and J.A. Hirsch. 1990. Binding of a Drosophila POU-domain protein to a sequence element regulating gene expression in specific dopaminergic neurons. Nature 342: 467-470.

Kemler, I. and W. Schaffner. 1990. Octamer transcription factors and the cell type-specificity of immunoglobulin gene expression. FASEB I. 4: 1444-1449.

Kemler, I., E. Bucher, K. Seipel, M. Müller-Immerglück, and W. Schaffner. 1990. Promoters with the octamer DNA motif (ATGCAAAT) can be ubiquitous or cell type-specific de- 
pending on binding affinity of the octamer site and Octfactor concentration. Nucleic Acids Res. 19: 237-242.

Ko, H-S., P. Fast, W. McBride, and L.M. Staudt. 1988. A human protein specific for the immunoglobulin octamer DNA motif contains a functional homeobox domain. Cell 55: 135144.

Kristie, T.M. and B. Roizman. 1984. Separation of sequences defining basal expression from those conferring $\alpha$ gene recogniton within the regulatory domains of herpes simplex virus $1 \alpha$ genes. Proc. Natl. Acad. Sci. 81: 4065-4069.

Kristie, T.M., J.H. LeBowitz, and P.A. Sharp. 1989. The octamerbinding proteins form multi-protein-DNA complexes with the HSV $\alpha$ TIF regulatory protein. EMBO I. 8: 4229-4238.

Laemmli, U.K. 1970. Cleavage of structural proteins during the assembly of the head of the bacteriophage $\mathrm{T}_{4}$. Nature 227: 680-685.

Landschulz, W.H., P.F. Johnson, S.L. McKnight. 1988. The leucine zipper: A hypothetical structure common to a new class of DNA binding proteins. Science 240: 1759-1764.

Larkin, S., S. Tait, M.N. Treacy, and F. Martin. 1990. Characterization of tissue-specific trans-factor binding to a proximal element in the rat growth hormone gene promoter. Eur. J. Biochem. 191: 605-615.

LeBowitz, J.H., R.G. Clerc, M. Brenowitz, and P.A. Sharp. 1989. The Oct-2 protein binds cooperatively to adjacent octamer sites. Genes \& Dev. 3: 1625-1638.

Li, S., E.B. Crenshaw III, E.J. Rawson, D.M. Simmons, L.W. Swanson, and M.G. Rosenfeld. 1990. Dwarf locus mutants, which lack three pituitary cell types, result from mutations in the POU-domain gene, Pit-1. Nature 347: 528-533.

Mangalam, H.J., V.R. Albert, H.A. Ingraham, M. Kapiloff, L. Wilson C. Nelson, H. Elsholtz, and M.G. Rosenfeld. 1989. A pituitary POU domain protein, Pit-1, activates both growth hormone and prolactin promoters transcriptionally. Genes \& Dev. 3: 946-958.

Murre, C., P.S. McCaw, and D. Baltimore. 1989a. A new DNA binding and dimerization motif in immunoglobulin enhancer binding, daughterless, MyoD, and myc proteins. Cell 56: 777-783.

Murre, C., P.S. McCaw, H. Vaessin, M. Caudy, L.Y. Jan, Y.N. Jan, C.V. Cabrera, J.N. Buskin, S.D. Hauschka, A.B. Lassar, $\mathrm{H}$. Weintraub, and D. Baltimore. 1989b. Interactions between heterologous helix-loop-helix proteins generate complexes that bind specifically to a common DNA sequence. Cell 58: $537-544$.

Nelson, C., V.R. Albert, H.P. Elsholtz, L.E.-W Lu, and M.G. Rosenfeld. 1988. Activation of cell-specific expression of rat growth hormone and prolactin genes by a common transcription factor. Science 239: 1400-1405.

Okamoto, K, H. Okazawa, A. Okuda, M. Sakai, M. Muramatsu, and H. Hamada. 1990. A novel octamer transcription factor is differentially expressed in mouse embryonic cells. Cell 60: $461-472$.

Ptashne, M. 1986. A genetic switch. Cell Press and Blackwell Publications, Cambridge MA.

Rauscher, F.J. III, T. Cohen, T.J. Curran, P.K. Bos, D. Vogt, D. Bohmann, R. Tjian, and B.R. Franza. 1988. Fos-associated protein (p39) is the product of the jun proto-oncogene. Science 240: 1010-1016.

Rosner, M.H., M.A. Vigano, K. Ozato, P.M. Timmons, F. Poirier, P.W.J. Rigby, and L.M. Staudt. 1990. A POU-domain transcription factor in early stem cells and germ cells of the mammalian embryo. Nature 345: 686-691.

Scheidereit, C., J.A. Cromlish, T. Gerster, K. Kawakami, C.-G. Balmaceda, R.A. Currie, and R.G. Roeder. 1988. A human lymphoid-specific transcription factor that activates immu- noglobulin genes in a homeobox protein. Nature 336: $552-$ 557.

Schöler, H.R., S. Ruppert, R. Balling, N. Suzuki, K. Chowdury, and P. Gruss. 1990. New type of POU domain in germ linespecific protein Oct-4. Nature 334: 435-439.

Schuster, W., M.N. Treacy, and F. Martin. 1987. Analysis of $\mathrm{GH}_{3}$ cell nuclear extract-prolactin gene promoter interactions by Exonuclease III protection. Biochem. Soc. Trans. 15: 953.

Simmons, D.M., J.W. Voss, H.A Ingram, J.M. Holloway, R.S. Broide, M.G. Rosenfeld, and L.W. Swanson. 1990. Pituitary cell phenotype involves cell-specific Pit-1 mRNA translation and synergistic interactions with other classes of transcription factors. Genes \& Dev. 4: 695-711.

Smith, D.B. and K.S. Johnson. 1988. Single-step purification of polypeptides expressed in Escherichia coli as fusions with glutathione S-transferase. Gene 67: 31-40.

Studier, F.W. and B.A. Moffat. 1986. Use of bacteriophage T7 RNA polymerase to direct selective high-level expression of cloned genes. J. Mol. Biol. 189: 13-23.

Sturm, R.A, G. Das and W. Herr. 1988. The ubiquitous octamerbinding protein Oct-1 contains a POU-domain with a homeo box subdomain. Genes \& Dev. 2: 1582-1599.

Tanaka, M. and W. Herr. 1990. Differential transcriptional activation by Oct-1 and Oct-2: Interdependent activation domains induce Oct-2 phosphorylation. Cell 60: 375-386.

Treacy, M.N., X. He, and M.G. Rosenfeld. 1991. I-POU: A novel POU-domain protein inhibiting neuron-specific gene activation via heterodimer formation. Nature 350: $577-584$.

Wirth, T., L. Staudt and D. Baltimore. 1987. An octamer oligonucleotide upstream of a TATA box is sufficient for lymphoid-specific promoter activity. Nature 329: 174-177. 


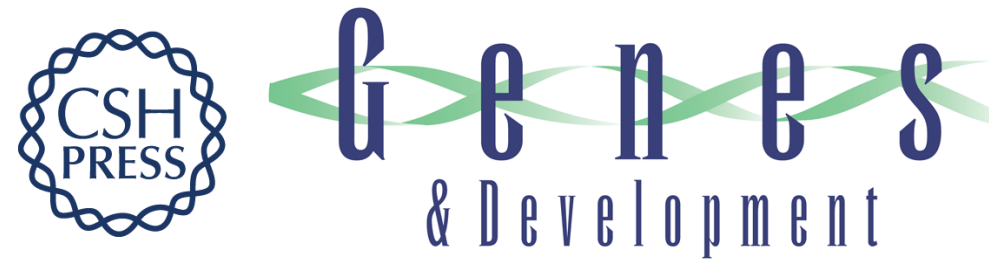

\section{POU-domain proteins Pit-1 and Oct-1 interact to form a heteromeric complex and can cooperate to induce expression of the prolactin promoter.}

J W Voss, L Wilson and M G Rosenfeld

Genes Dev. 1991, 5:

Access the most recent version at doi:10.1101/gad.5.7.1309

References This article cites 51 articles, 19 of which can be accessed free at: http://genesdev.cshlp.org/content/5/7/1309.full.html\#ref-list-1

License

Email Alerting Service

Receive free email alerts when new articles cite this article - sign up in the box at the top right corner of the article or click here.

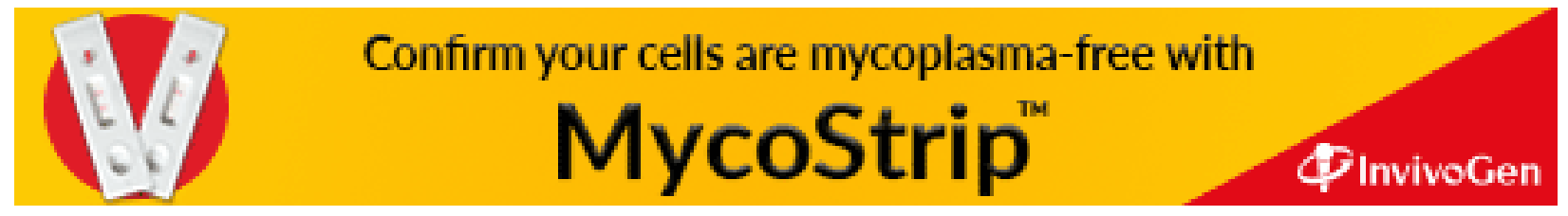

